\title{
Editorial
}

\section{Ancianos coraje, hoy}

Hoy no son mis protagonistas aquellos mediáticos veteranos que en justa lucha demostraron, en plaza pública o a cubierto, tesón, paciencia y esperanza en encontrar respuesta y justicia, dando muestra y lección de su férrea hechura y de su fe.

Estas páginas nos recuerdan hoy aquel retrato sobre un creciente grupo de mayores, modelados por sometimientos prolongados en misiones de custodia de nietos y otras labores domésticas, consentidos en inicio, impuestos, soportados y acallados por vía genética, en casos aborrecidos por la abusiva intensidad y responsabilidad no reconocida y que han alumbrado encubiertas nuevas formas de esclavitud.

Hoy, la más rigurosa y trágica actualidad da vida a la historia de dos nuevos grupos de ancianos que me van permitir presente como verdaderos "ancianos coraje".

Se trata, las más de las veces, de progenitores en la séptima u octava década de su vida que han visto cómo en los últimos meses no les despierta la obligación ya cotidiana de acudir a la llamada de ayuda para tareas domésticas o el cuidado de sus nietos, por estrictos "motivos laborales", sino que no son capaces de conciliar el sueño porque de la noche a la mañana han visto cómo se ha vuelto a poblar su vivienda con aquellos que marcharon y que construyeron un nuevo nido y núcleo familiar, en el que hoy no pueden seguir viviendo. Llegan hijos y los hijos de los hijos cargados de pérdidas en batallas cotidianas, sin trabajo, sin ahorros, solo deudas, y buscando a alguien que les ayude expresamente a sobrevivir. A menudo, recursos nulos, piso embargado, relaciones personales también en riesgo de quiebra por una situación financiera inesperada y obligados a llamar en la puerta de los que bien saben que nunca les dejarán de ayudar.

Un nuevo panorama, de convivencia forzada, de limitaciones de espacio, de ahorros y pensiones raquíticas que precisan elongarse como nunca para cubrir las necesidades más básicas, ahora hipotecadas. Admiro a esos muchos que hoy, abnegadamente y con la sonrisa eterna del progenitor, consuelan a los que han regresado, suavizan las tensiones que generan épocas de dificultad, reclutan energías para seguir sosteniendo el equilibrio del grupo, olvidan sus necesidades, sus fatigas, sus padecimientos, como en otras épocas, porque ahora no es posible. La mirada hacia delante, el objetivo, el de siempre, el de ayudar. Mis dolencias pueden esperar, ahora de nuevo me necesitan.

Pero todavía, en este momento en el que la crisis es franca y sin claros en el horizonte que alimenten la esperanza, se están recreando nuevas historias que envuelven a algunos mayores y que parecen extraídas de la más pura ficción. Se trata de algunos mayores que llevaban tiempo atrás viviendo en centros residenciales, porque entendemos, sin acritud, que las condiciones personales y su entorno de cuidados lo propició, y que hoy son "rescatados", regresan a la casa de aquellos que no pudieron atenderlos en su momento, y que han descubierto que el costo de aquella plaza sufraga el gasto de toda la familia, ahora en serias dificultades. Bendito anciano, convertido en papel moneda, y que a pesar de su dependencia, sigue, como el Cid Campeador, resolviendo situaciones de horror.

Hoy, ante estas nuevas escenas sociológicas, que seguro tienen otras muchas réplicas de igual rocambolesca, quisiera hacer un amplio llamamiento, por una parte de reconocimiento público para esos ancianos coraje que reaparecen como héroes en momentos de conflicto, de consideración, respeto y buen trato por parte de los que están recibiendo su cuidado impreso con su último aliento, de detección y protección por parte de las administraciones y profesionales gerontológicos porque se agregan nuevos sumandos al amplio abanico de ancianos frágiles. Un semblante vulnerable sobre el que de nuevo se sostiene una "gran familia". 